\title{
Eating Patterns in Patients with Compensated Cirrhosis: A Case-Control Study
}

\author{
Camille Buscail ${ }^{1,2, *}$, Valérie Bourcier ${ }^{3}$, Léopold K. Fezeu ${ }^{1}$, Dominique Roulot ${ }^{4,5}$, \\ Séverine Brulé ${ }^{3}$, Zahia Ben-Abdesselam ${ }^{4}$, Carole Cagnot ${ }^{6}$ (i), Serge Hercberg ${ }^{1,2}$ (1), \\ Pierre Nahon ${ }^{3,5,7}$, Nathalie Ganne-Carrié ${ }^{3,5,7, \dagger}$ and Chantal Julia ${ }^{1,2, \dagger}$ \\ 1 Nutritionnal Epidemiology Research Team (EREN), Paris 13 University, UMR U1153 Inserm, \\ Inra U1125, Cnam, Center of Reasearch in Epidemiology and Biostatistics (CRESS) Sorbonne Paris Cité, \\ 75004 Paris, France; 1.fezeu@eren.smbh.univ-paris13.fr (L.K.F.); s.hercberg@eren.smbh.univ-paris13.fr (S.H.); \\ c.julia@eren.smbh.univ-paris13.fr (C.J.) \\ 2 Public Health Department, University Hospitals of Paris Seine-Saint-Denis, APHP, Avicenne Hospital, \\ 93000 Bobigny, France \\ 3 Hepatology Department, University Hospitals of Paris Seine-Saint-Denis, APHP, Jean Verdier Hospital, \\ 93140 Bondy, France; valerie.bourcier@aphp.fr (V.B.); mec.hge.jvr@aphp.fr (S.B.); \\ pierre.nahon@aphp.fr (P.N.); nathalie.ganne@aphp.fr (N.G.-C.) \\ 4 Hepatology Unit, University Hospitals of Paris Seine-Saint-Denis, APHP, Avicenne Hospital, \\ 93000 Bobigny, France; dominique.roulot@aphp.fr (D.R.); zahia.ben-abdesselam@aphp.fr (Z.B.-A.) \\ 5 Formation and Research Unit in Health Medicine and Human Biology, Paris 13 University, \\ Sorbonne Paris Cité, 93430 Paris, France \\ 6 Hepatitis Department ANRS (France Recherche Nord \& Sud, SIDA-VIH-Hépatites), 75013 Paris, France; \\ carole.cagnot@inserm.fr \\ 7 UMR 1162 Inserm, Universités Paris 5, Paris 7 and Paris 13, 75006 Paris, France \\ * Correspondence c.buscail@eren.smbh.univ-paris13.fr; Tel.: +33-148-388-977 \\ + Last co-author.
}

Received: 6 November 2017; Accepted: 9 January 2018; Published: 10 January 2018

\begin{abstract}
Background: There is growing evidence suggesting that maintaining an adequate nutritional status for patients with liver cirrhosis (LC) is relevant to prevent complications. The present study aimed to describe dietary behaviours of patients with compensated and non-complicated LC and comparing them with those of subjects from the general population. Methods: In this case-control study, patients were volunteers enrolled in the ALICIR (ALImentation et CIRrhose) study, an observational survey nested in two French prospective cohorts of patients with biopsy-proven compensated cirrhosis related either to excessive alcohol consumption (CIRRAL) or to hepatitis B or C virus infection (CirVir). Controls were selected from the NutriNet-Santé cohort. Dietary data were collected through a semi quantitative food frequency questionnaire. Dietary and nutritional data were compared using multi-adjusted paired Student's tests. Results: Between June 2014 and February 2016, 174 patients of CirVir $(N=97)$ or CIRRAL $(N=77)$ were matched with 348 controls from the NutriNet-Santé cohort, according to gender, age, BMI and educational level. Compared to controls, patients (mean $\pm \mathrm{SD})$ consumed more sodas $(236.0 \pm 29.8 \mathrm{~mL}$ vs. $83.0 \pm 33.0 \mathrm{~mL})$ and water $(1787.6 \pm 80.6 \mathrm{~mL}$ vs. $933.6 \pm 85.3 \mathrm{~mL})$, and lower amounts of salty snacks $(4.2 \pm 1.42 \mathrm{~g}$ vs. $9.0 \pm 1.6 \mathrm{~g})$ and alcoholic beverages $(71.8 \pm 23.4 \mathrm{~g}$ vs. $151.2 \pm 25.9 \mathrm{~g})$, with all $p$ values $<0.0001$. Dietary behaviours differed according to LC aetiology. Conclusions: Dietary behaviour of patients significantly differed from subjects from the general population.
\end{abstract}

Keywords: liver cirrhosis; alcoholic cirrhosis; viral cirrhosis; dietary intakes; nutritional status

\section{Introduction}

There is growing evidence suggesting that maintaining an adequate and balanced nutritional status for patients with liver cirrhosis (LC) is of importance. Associations between nutritional factors 
and long-term complications of LC have been identified, mainly in patients with decompensated forms or marked liver failure. For instance, protein-energy malnutrition (PEM) has been suggested to result in a greater risk of more severe complications such as ascites, encephalopathy, and infections. PEM has also been identified as an independent risk factor for death in patients with LC, regardless of the aetiology [1-5]. Moreover, long-term high protein and energy intakes resulting in overweight and insulin resistance could hasten the progression of the disease [6,7]. Similar results were shown for higher dietary cholesterol intakes [8]. More recently, Berzigotti and colleagues have shown that moderate physical activity could lead to the reduction of portal hypertension and, therefore, to a reduced risk of complications [9]. However, the dietary components involved as independent risk or protection factors of complication or mortality in LC remain largely uncertain. A few studies have focused on the dietary behaviour and lifestyle data of patients with compensated cirrhosis without significant liver failure and/or portal hypertension. They showed heterogeneous results, with no clear difference between patients and controls. However, most of them were performed in Asia, on a reduced number of patients [10-13]. Assessing dietary behaviour of LC patients during the early phase of the disease, therefore, appears essential to increase the knowledge in this domain among western populations, and to identify the role of nutritional factors in disease progression. The ALICIR (ALImentation et CIRrhose) longitudinal study was set-up to assess the dietary behaviours, lifestyle (including physical activity) and exposure to environmental factors among patients with compensated viral or alcoholic cirrhosis, and relate them to the occurrence of subsequent complications, in particular hepatocellular carcinoma (HCC). All patients have been enrolled and are ongoing close follow-up to reach critical number of events. The present cross-sectional study aimed at describing dietary behaviours of patients with compensated and non-complicated cirrhosis and comparing them with those of subjects from the general population.

\section{Materials and Methods}

\subsection{Design of the Study}

This study is based on a case-control design. The cases were recruited in two tertiary French liver units involved in the ALICIR study: Avicenne and Jean Verdier hospitals. Both these university institutions are located in the Seine-Saint-Denis district (Northeast Paris suburbs).

\subsection{Study Population}

The study population included all patients participating in the ALICIR study. The objective of the ALICIR study is to describe dietary, lifestyle, and environmental factors in LC patients and to relate them to LC complications, in particular HCC. The ALICIR study is a longitudinal cohort study nested in two French prospective cohorts of patients with cirrhosis: the ANRS CO12 CirVir and CIRRAL (Figure 1) cohorts.

The CirVir cohort included 1671 patients with histologically proven viral compensated cirrhosis, from 35 clinical centres dedicated to hepatic diseases management from March 2006 to December 2012. Excessive alcohol consumption was not an exclusion criterion. Patients included in this study receive a prospective follow-up according to French and international guidelines. This study has been fully described elsewhere [14].

The CIRRAL cohort was initiated in 2010 and included 652 patients with alcohol-related compensated cirrhosis, histologically proven, with or without HIV coinfection but without HBV or HCV infection from 22 clinical centres dedicated to hepatic diseases (ClinicalTrials.gov: number NCT01213927). Details about this study have been previously described [15].

The ALICIR study included patients enrolled in CirVir or CIRRAL between June 2014 and February 2016 in 2 tertiary liver units from the same area (north-east Paris' suburb, University Paris 13). All patients from the CirVir or CIRRAL cohorts, who came at these hospitals for an inclusion or a follow-up visit during that period of time, and matching inclusion/exclusion ALICIR criteria, 
were proposed to be included in the ALICIR study. Inclusion criteria for the ALICIR study were the following: (i) included and followed-up in CirVir or CIRRAL; (ii) no detectable HCC within 90 days prior to the inclusion; (iii) signed free and informed consent. Exclusion criteria were: (i) no social insurance; (ii) lack of French-language skills; (iii) any episode of hepatic decompensation during the timeframe elapsing between CIRRAL or CirVir and ALICIR inclusion.

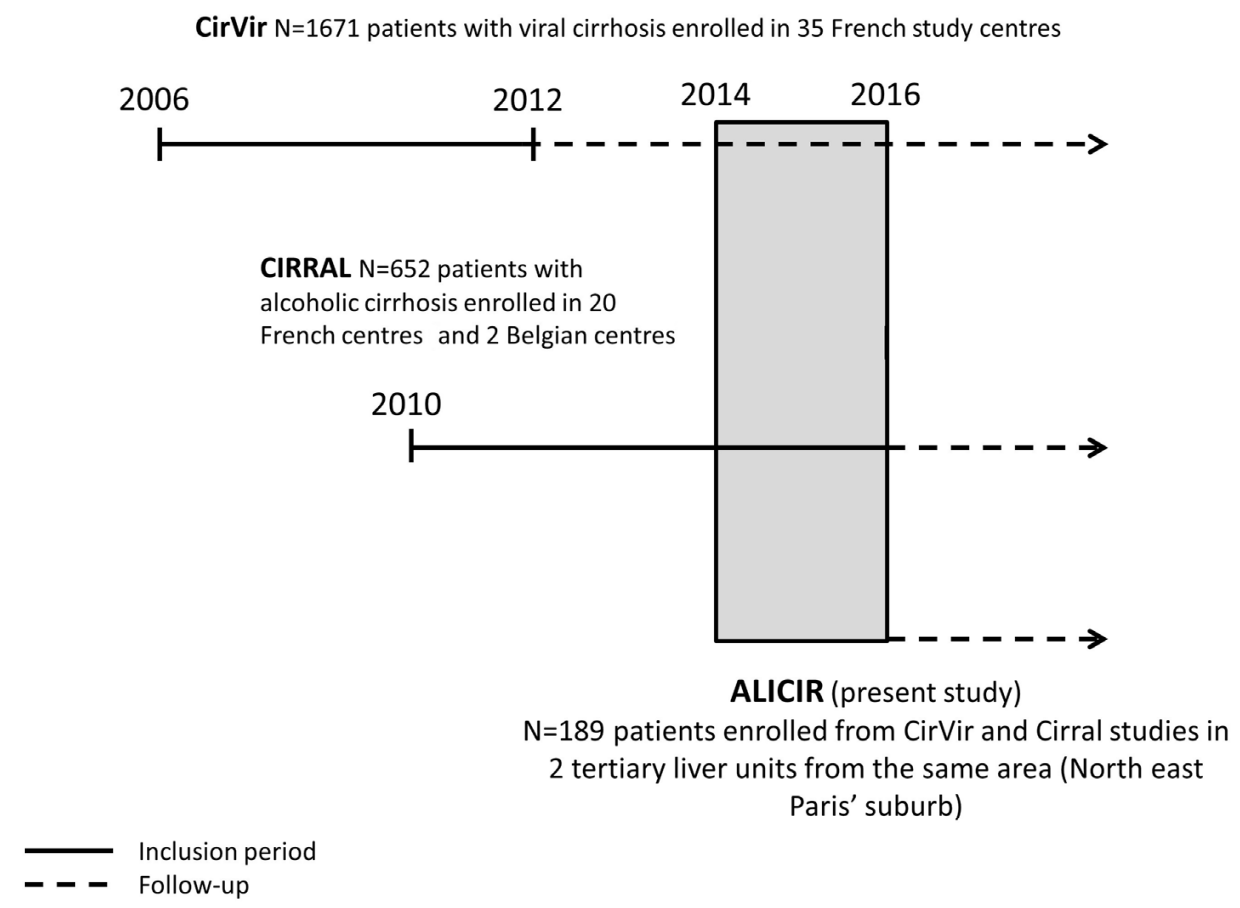

Figure 1. Description of patient selection.

Controls were selected from the NutriNet-Santé Cohort (two controls were included for one patient from ALICIR). The NutriNet-Santé study is a web-based prospective observational cohort. Details on this study have been previously described [16]. Briefly, the NutriNet-Santé study aims at investigating the dietary behaviours of subjects from the general population, and their relationships with health. The inclusion of subjects aged over 18 years started in France in May 2009 and still ongoing with more than 158,000 subjects enrolled at the time of the study. At baseline, participants completed self-administered questionnaires about socio-economic, lifestyle, health status, diet, physical activity, and anthropometrics data. This set of questionnaires is repeated yearly. Moreover, during follow-up, additional questionnaires are regularly proposed on various subjects pertaining to the investigation of determinants of dietary pattern on health.

\subsection{Ethics}

The ALICIR study was approved by the French Advisory Committee for Data Processing in Health Research of the French Ministry of Health and Medical Research (CCTIRS) (file No. 13.501) and the Commission Nationale de 1'Informatique et des Libertés (CNIL) (No. DR-2014-219). All patients from ALICIR study gave written informed consent before inclusion. The CirVir protocol obtained approval from the ethics committee (Comité de Protection des Personnes, Aulnay-sous-Bois, France) and conformed to the ethical guidelines of the 1975 Declaration of Helsinki. The full CirVir protocol is available via the ANRS website [17]. All patients gave written informed consent to participate in the cohort. The NutriNet-Santé Study is set in accordance with the declaration of Helsinki and was approved by the institute Review Board of the French Institute for Health and Medical Research (00000388FWA00005831) and the CNIL (No. 908450 and 909216). All participants provided an electronic informed consent. 


\subsection{Data Collection}

\subsubsection{Dietary Data}

At inclusion in ALICIR, a semi-quantitative food frequency questionnaire validated for the French population [18] was administered to patients by a trained dietician (about $1 \mathrm{~h}$ in duration). The questionnaire included 240 food and beverage items, categorized in 24 food groups. For each group portion size are estimated using either usual containers (for example spoon or standard unit as yogurt) or a set of validated color photographs (for example, three different plates with various portions of pastas are used for the assessment of starches consumption). This questionnaire is based on the food frequency questionnaire validated in the French cohort SU.VI.MAX [19]. Unless they needed specific dietary advices related to other chronic conditions such as diabetes, obesity or heart failure, patients did not benefit from a dietary counselling before the completion of the questionnaire. Dietary data for controls were collected using an identical questionnaire, also self-administered online, sent to each participant eight months after inclusion in the NutriNet-Santé study. Both cases and control were asked to recall their intake over the previous 12 months.

\subsubsection{Covariates}

Data about lifestyle (marital status, educational level, socioeconomic status, smoking status, physical activity level, weight history, native country, and length of stay in France for patients born in foreign countries); nutritional behaviours (alcohol consumption, and food supply), environmental exposure, and medical history (such as high blood pressure, diabetes); and current treatment were collected at inclusion in both studies using similar questionnaires.

\subsubsection{Patients' Characteristics}

At inclusion in the ALICIR study, patients completed self-reported questionnaires on sociodemographic data (age, gender, marital status, educational level, professional status, living place, country of birth), family medical history of liver cancer, smoking status and cannabis use, weight and weight change over the last five years. Physical activity level was assessed using the International Physical Activity Questionnaire (IPAQ) at baseline, and the Metabolic Equivalent of Task (MET) scores based on the classification of Ainsworth [20] were used to calculate a total MET for each volunteer. Subjects are classified according to their total level of physical activity (1: subjects highly physically active; 2: subjects with intermediate level of total physical activity; 3 : subjects with low level of total physical activity) according to the IPAQ guidelines [20].

\subsubsection{Controls' Characteristics}

At baseline, information on age, gender, body mass index (BMI) (normal/overweight or obese), smoking status (current smoker/former smoker/nonsmoker), marital status (single/cohabiting), monthly income level (<1200€ per consumer unit (c.u.)/1200-2300 € per c.u./>2300 € per c.u.) [21] and educational level (no diploma or primary studies/secondary studies or higher educational level) were collected by self-administered questionnaire. Physical activity level was assessed using International Physical Activity Questionnaire (IPAQ) at baseline [20].

\subsection{Statistical Analysis}

Controls (two for one case) were selected among participants in the NutriNet-Santé study residing in the same geographical region as the two sites of inclusion in the ALICIR study. Moreover, cases and controls were matched according to their gender, age (five years), BMI $\left(<25 \mathrm{~kg} / \mathrm{m}^{2}\right.$, [25-30), $\geq 30 \mathrm{~kg} / \mathrm{m}^{2}$ ), and educational level (no diploma and primary, secondary school, superior). The comparison of sociodemographic and lifestyle data between case and control groups was performed using chi-square tests. Comparison of food group consumption and nutrients intake between cases and controls was realized, using ANCOVA tests, and was controlled at least for occupational level, marital status, smoking status, physical activity. Analyses were also controlled for 
total energy intake for alcohol. Comparison of water consumption was further controlled for diabetes status and diuretic treatment. Data on intakes of saturated fatty acids (SFA), monounsaturated fatty acids (MUFA), polyunsaturated fatty acids (PUFA), beta-carotene, and vitamins A, B12, C, and E were first log transformed to comply with normal distribution. Vitamins intakes were compared between cases and controls according to the prevalence of nutrient inadequacy regarding the French estimated average requirements (EAR) (i.e., the proportion of subjects with reported intakes below the EAR). This prevalence represents an unbiased estimate of the proportion of subjects whose intakes are below their respective requirements [22]. We relied upon the French references updated in 2016 to compute the prevalence of nutrient inadequacy in both groups [23]. These proportions were then compared between cases and controls using chi-square tests. All tests of significance were two-sided and the type I error was set at $10^{-3}$, given the high number of tests performed. All analyses were carried out using SAS software (version 9.4; SAS Institute, Inc., Cary, NC, USA) [24].

\section{Results}

Between June 2014 and February 2016, 189 patients completed (at least partially) the dietary questionnaire. Two patients were excluded because they did not meet the inclusion criteria. Four questionnaires were excluded because answers were missing for at least 10 items in the questionnaire. One patient reporting $178 \mathrm{kcal}$ of daily energy intake was excluded. Finally, 182 patients included in the ALICIR study had complete dietary data available for analysis. Matching between cases and controls was available for 174 patients of the ALICIR study. Subjects for which controls could not be selected in the NutriNet-Santé study were all aged $>80$ years old and with low educational levels. Thus, data for 174 cases and 348 controls were used for this study (Figure 2). Patients were mainly men (72.4\%) aged between 55 and 65 years (39.7\%, mean age \pm SD was $59.1 \pm 9.7$ years), with an increased BMI $\left(62.1 \%\right.$ over $\left.25 \mathrm{~kg} / \mathrm{m}^{2}\right)$. Less than a half of patients were born in France $(N=83$, $47.7 \%)$. Others patients were born in Sub-Saharan Africa $(N=28,16.1 \%)$, in Europe (except France, $N=22,12.6 \%)$, in Maghreb $(N=21,12.1 \%)$, and in Asia or America $(N=20,11.4 \%)$. Forty-nine patients (33.1\%) $(N=27$ in alcoholic LC and $N=22$ in viral LC) were suffering from diabetes and $48(32.4 \%)$ from high blood pressure ( $N=18$ in alcoholic LC and $N=30$ in viral LC) $(N=26$ missing data for the both variables). Except for the marital status for which no significant difference was observed between patients and controls, the cases from ALICIR were more likely to be on disability leave from work, more often smokers and had a lower physical activity level (all $p$ values were $<0.0001)($ Table 1 ). These sociodemographic differences between cases and controls were similar according to the different aetiologies of the cirrhosis (Table 2).

Table 1. Comparison of sociodemographic characteristics for cases and controls $(N=522)$.

\begin{tabular}{|c|c|c|c|c|c|}
\hline & \multicolumn{2}{|c|}{ ALICIR } & \multicolumn{2}{|c|}{ NutriNet } & \multirow{2}{*}{$p^{*}$} \\
\hline & $N$ & $\%$ & $N$ & $\%$ & \\
\hline & 174 & & 348 & & \\
\hline \multicolumn{6}{|l|}{ Gender } \\
\hline Male & 126 & 72.4 & 252 & 72.4 & 1.00 \\
\hline Female & 48 & 27.6 & 96 & 27.6 & \\
\hline \multicolumn{6}{|l|}{ Age (years) } \\
\hline$\leq 45$ & 12 & 6.9 & 24 & 6.9 & \\
\hline $45-54.9$ & 41 & 23.6 & 82 & 23.6 & \\
\hline $55-64.9$ & 69 & 39.7 & 138 & 39.7 & 1.00 \\
\hline $65-74.9$ & 41 & 23.6 & 82 & 23.6 & \\
\hline$\geq 75$ & 11 & 6.3 & 22 & 6.3 & \\
\hline \multicolumn{6}{|c|}{ BMI $\left(\mathrm{kg} / \mathrm{m}^{2}\right)$} \\
\hline$<25$ & 66 & 37.9 & 132 & 37.9 & \\
\hline$[25-30)$ & 67 & 38.5 & 134 & 38.5 & 1.00 \\
\hline$\geq 30$ & 41 & 23.6 & 82 & 23.6 & \\
\hline
\end{tabular}


Table 1. Cont

\begin{tabular}{|c|c|c|c|c|c|}
\hline & \multicolumn{2}{|c|}{ ALICIR } & \multicolumn{2}{|c|}{ NutriNet } & \multirow{2}{*}{$p^{*}$} \\
\hline & $N$ & $\%$ & $N$ & $\%$ & \\
\hline \multicolumn{6}{|l|}{ Education level } \\
\hline No diploma or primary school & 119 & 68.4 & 238 & 68.4 & \multirow{3}{*}{1.00} \\
\hline Secondary & 21 & 12.1 & 42 & 12.1 & \\
\hline High education level & 34 & 19.5 & 68 & 19.5 & \\
\hline \multicolumn{6}{|l|}{ Marital status } \\
\hline Single & 57 & 32.8 & 91 & 26.1 & \multirow[t]{2}{*}{0.11} \\
\hline Cohabiting & 117 & 67.2 & 257 & 73.8 & \\
\hline \multicolumn{6}{|l|}{ Professional status } \\
\hline Working & 68 & 39.1 & 141 & 40.5 & \multirow{3}{*}{$<0.0001$} \\
\hline Unemployed & 88 & 50.6 & 202 & 58.0 & \\
\hline Sick leave & 18 & 10.3 & 5 & 1.4 & \\
\hline \multicolumn{6}{|l|}{ Smoking status } \\
\hline Former or non-smoker & 123 & 70.7 & 313 & 89.9 & \multirow[t]{2}{*}{$<0.0001$} \\
\hline Current smoker & 51 & 29.3 & 35 & 10.1 & \\
\hline \multicolumn{6}{|l|}{ Physical activity level } \\
\hline High & 25 & 14.4 & 147 & 42.2 & \multirow{4}{*}{$<0.0001$} \\
\hline Moderate & 88 & 50.6 & 121 & 34.8 & \\
\hline Low & 47 & 27.0 & 80 & 23.0 & \\
\hline Missing & 14 & 8.0 & 0 & 0.00 & \\
\hline
\end{tabular}

Abbreviations: BMI: Body Mass Index. ${ }^{*}$ Chi-square tests were performed.

Table 2. Comparison of sociodemographic characteristics for cases and controls stratified on the aetiology of cirrhosis $(N=522)$.

\begin{tabular}{|c|c|c|c|c|c|c|c|c|c|c|}
\hline & \multirow{2}{*}{\multicolumn{2}{|c|}{$\begin{array}{c}\text { ALICIR } \\
\text { Alcoholic } \\
\text { Cirrhosis }\end{array}$}} & \multirow{2}{*}{\multicolumn{2}{|c|}{ NutriNet }} & \multirow{2}{*}{\multicolumn{3}{|c|}{$\begin{array}{c}\text { ALICIR } \\
\text { Viral } \\
\text { Cirrhosis }\end{array}$}} & \multirow{2}{*}{\multicolumn{2}{|c|}{ NutriNet }} & \multirow[b]{3}{*}{$p^{*}$} \\
\hline & & & & & & & & & & \\
\hline & $N$ & $\%$ & $N$ & $\%$ & $p^{*}$ & $N$ & $\%$ & $N$ & $\%$ & \\
\hline & 77 & & 154 & & & 97 & & 194 & & \\
\hline \multicolumn{11}{|l|}{ Gender } \\
\hline Men & 58 & 75.3 & 116 & 75.3 & \multirow[t]{2}{*}{1.00} & 68 & 70.1 & 136 & 70.1 & \multirow[t]{2}{*}{1.00} \\
\hline Women & 19 & 24.6 & 38 & 24.7 & & 29 & 29.9 & 58 & 29.9 & \\
\hline \multicolumn{11}{|l|}{ Age } \\
\hline$\leq 45$ years & 1 & 1.3 & 2 & 1.3 & \multirow{5}{*}{1.00} & 11 & 11.3 & 22 & 11.3 & \multirow{5}{*}{1.00} \\
\hline $45-55$ years & 18 & 23.4 & 36 & 23.4 & & 23 & 23.7 & 46 & 23.7 & \\
\hline 55-65 years & 31 & 40.3 & 42 & 40.3 & & 38 & 39.2 & 76 & 39.2 & \\
\hline $65-75$ years & 24 & 31.2 & 48 & 31.2 & & 17 & 1.5 & 34 & 17.5 & \\
\hline$>75$ years & 3 & 3.9 & 6 & 3.9 & & 8 & 8.2 & 16 & 8.2 & \\
\hline \multicolumn{11}{|l|}{ BMI } \\
\hline$<25$ & 25 & 32.4 & 50 & 32.5 & \multirow{3}{*}{1.00} & 41 & 42.3 & 82 & 42.3 & \multirow{3}{*}{1.00} \\
\hline$[25-30)$ & 27 & 35.1 & 54 & 35.1 & & 40 & 41.2 & 80 & 41.2 & \\
\hline$\geq 30$ & 25 & 32.5 & 50 & 32.5 & & 16 & 16.5 & 32 & 16.5 & \\
\hline \multicolumn{11}{|l|}{ Education level } \\
\hline No diploma or primary school & 55 & 71.4 & 110 & 71.4 & \multirow{3}{*}{1.00} & 64 & 66.0 & 128 & 66.0 & \multirow{3}{*}{1.00} \\
\hline Secondary & 7 & 9.1 & 14 & 9.1 & & 14 & 14.4 & 28 & 14.4 & \\
\hline High education level & 15 & 19.5 & 30 & 19.5 & & 19 & 19.6 & 38 & 19.6 & \\
\hline \multicolumn{11}{|l|}{ Marital status } \\
\hline Single & 28 & 36.4 & 40 & 26.0 & \multirow[t]{2}{*}{0.10} & 29 & 29.9 & 51 & 26.3 & \multirow[t]{2}{*}{0.52} \\
\hline Cohabiting & 49 & 63.6 & 114 & 74.0 & & 68 & 70.1 & 143 & 73.7 & \\
\hline \multicolumn{11}{|l|}{ Professional status } \\
\hline Employed & 20 & 26.0 & 52 & 33.8 & \multirow{3}{*}{0.002} & 48 & 49.5 & 89 & 45.9 & \multirow{3}{*}{0.003} \\
\hline Unemployed & 47 & 61.0 & 99 & 64.3 & & 41 & 42.3 & 103 & 53.1 & \\
\hline Sick leave & 10 & 13.0 & 3 & 1.9 & & 8 & 8.2 & 2 & 1.0 & \\
\hline
\end{tabular}


Table 2. Cont.

\begin{tabular}{|c|c|c|c|c|c|c|c|c|c|c|}
\hline & \multirow{2}{*}{\multicolumn{2}{|c|}{$\begin{array}{c}\text { ALICIR } \\
\text { Alcoholic } \\
\text { Cirrhosis }\end{array}$}} & \multirow{2}{*}{\multicolumn{2}{|c|}{ NutriNet }} & & \multirow{2}{*}{\multicolumn{2}{|c|}{$\begin{array}{c}\text { ALICIR } \\
\text { Viral } \\
\text { Cirrhosis }\end{array}$}} & \multirow{2}{*}{\multicolumn{2}{|c|}{ NutriNet }} & \multirow[b]{3}{*}{$p^{*}$} \\
\hline & & & & & & & & & & \\
\hline & $N$ & $\%$ & $N$ & $\%$ & $p^{*}$ & $N$ & $\%$ & $N$ & $\%$ & \\
\hline \multicolumn{11}{|l|}{ Smoking status } \\
\hline Former or non smoker & 47 & 61.0 & 140 & 90.9 & $<0.0001$ & 76 & 78.3 & 173 & 89.2 & 0.01 \\
\hline Current smoker & 30 & 39.0 & 14 & 9.19 & & 21 & 21.6 & 21 & 10.8 & \\
\hline \multicolumn{11}{|l|}{ Physical activity level } \\
\hline High & 9 & 11.7 & 56 & 36.4 & & 16 & 16.5 & 91 & 46.9 & \\
\hline Moderate & 41 & 53.2 & 60 & 39.0 & $<0.0001$ & 47 & 48.4 & 61 & 31.4 & $<0.0001$ \\
\hline Low & 20 & 26.0 & 38 & 24.7 & & 27 & 27.8 & 42 & 21.6 & \\
\hline Missing & 7 & 9.1 & 0 & & & 7 & 7.2 & 0 & & \\
\hline
\end{tabular}

Abbreviations: BMI: Body Mass Index. ${ }^{*}$ Paired Chi-square tests were performed.

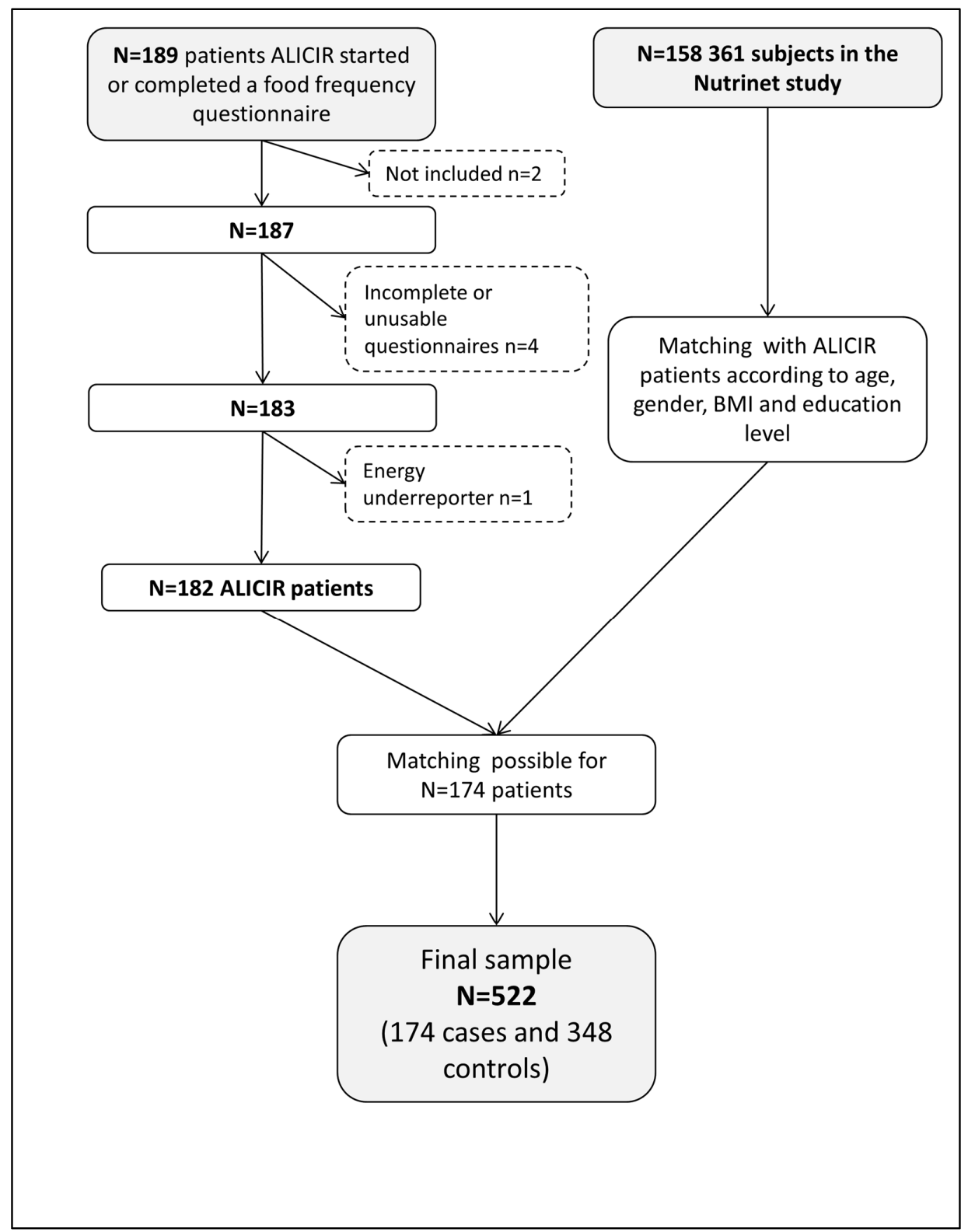

Figure 2. Flowchart of the study. 


\subsection{Comparison of Dietary Intakes}

Overall, compared to the NutriNet-Santé study controls, patients consumed higher amounts of sodas $(236.0 \pm 29.8 \mathrm{~mL}$ vs. $83.0 \pm 33.0 \mathrm{~mL}, p<0.0001)$ and water $(1787.6 \pm 80.6 \mathrm{~mL}$ vs. $933.6 \pm 85.3 \mathrm{~mL}$, $p<0.0001)$. Conversely, they ate less legumes, salty snacks, vegetable fat, and drank fewer alcoholic beverages (Table 3). Dietary behaviours somewhat differed according to LC aetiology: subjects with alcoholic LC showed higher intakes in sweet products (i.e., marmalade, confectionery and honey) compared to the control group (supplemental Table S1). The patients with viral LC showed lower consumptions of legumes, processed meat, desserts, and salty snacks.

Table 3. Comparison of adjusted dietary intakes between controls and cases $(N=522)$.

\begin{tabular}{|c|c|c|c|}
\hline & $\begin{array}{l}\text { ALICIR Mean } \\
\text { (SD) }\end{array}$ & $\begin{array}{l}\text { NutriNet Mean } \\
\text { (SD) }\end{array}$ & $p^{*}$ \\
\hline$N$ & 174 & 348 & \\
\hline Fruits (g/day) & $205.9(25.1)$ & $258.1(27.7)$ & 0.18 \\
\hline Vegetables (g/day) & $276.9(22.3)$ & $317.2(24.7)$ & 0.12 \\
\hline Cereal bread (g/day) & $142.2(8.1)$ & $125.225(9.0)$ & 0.09 \\
\hline Potatoes (g/day) & $35.1(2.9)$ & $29.1(3.2)$ & 0.03 \\
\hline Pasta, rice, semolina (g/day) & $117.2(9.9)$ & $98.8(11.1)$ & 0.01 \\
\hline Legumes (g/day) & $14.6(2.6)$ & $26.0(2.9)$ & $<0.0001$ \\
\hline Milk (g/day) & $142.4(21.4)$ & $116.0(23.6)$ & $<0.01$ \\
\hline Dairy products (g/day) & $159.9(18.0)$ & $193.1(19.8)$ & 0.02 \\
\hline Cheese (g/day) & $36.3(5.4)$ & $50.8(5.9)$ & $<0.01$ \\
\hline Fish and seafood (g/day) & $39.6(5.4)$ & $50.9(6.0)$ & 0.03 \\
\hline Meat (g/day) & $101.4(8.0)$ & $99.0(8.9)$ & 0.88 \\
\hline Poultry (g/day) & $27.8(2.9)$ & $21.1(3.2)$ & $<0.01$ \\
\hline Organ meat (g/day) & $6.0(1.0)$ & $7.4(1.1)$ & 0.03 \\
\hline Eggs (g/day) & $15.9(1.4)$ & $12.7(1.6)$ & 0.05 \\
\hline Processed meat (g/day) & $9.1(1.8)$ & $8.8(2.0)$ & 0.06 \\
\hline Desserts (g/day) & $23.2(4.8)$ & $15.7(5.3)$ & 0.28 \\
\hline Marmelade, confectionery and honey (g/day) & $29.4(2.3)$ & $23.0(2.5)$ & $<0.01$ \\
\hline Cakes and cookies (g/day) & $28.0(3.3)$ & $28.4(3.7)$ & 0.05 \\
\hline Salty snacks (g/day) & $4.2(1.4)$ & $9.0(1.6)$ & $<0.0001$ \\
\hline Sauces (g/day) & $18.4(1.2)$ & $9.4(1.3)$ & $<0.0001$ \\
\hline Animal fat (g/day) & $4.5(0.8)$ & $6.3(0.8)$ & 0.48 \\
\hline Vegetable fat (g/day) & $14.2(2.1)$ & $20.0(2.3)$ & $<0.001$ \\
\hline Water (g/day) & $1787.6(80.6)$ & $933.6(85.3)$ & $<0.0001$ \\
\hline Soft beer (g/day) & $9.0(6.5)$ & $9.0(7.2)$ & 0.86 \\
\hline Sodas (g/day) & $236.0(29.8)$ & $83.0(33.0)$ & 0.0001 \\
\hline Alcoholic beverages (g/day) & $71.8(23.4)$ & $151.2(25.9)$ & $<0.0001$ \\
\hline Coffee (g/day) & $131.3(18.6)$ & $178.8(20.5)$ & $<0.01$ \\
\hline Tea (g/day) & $101.0(26.7)$ & $140.1(29.5)$ & 0.03 \\
\hline Soft and non-sugared beverages ( $\mathrm{g} /$ day) & $59.5(16.0)$ & $86.1(17.7)$ & $<0.01$ \\
\hline
\end{tabular}

${ }^{*}$ ANCOVA tests adjusted for: marital status, professional status, smoking status, and physical activity. Water intakes were also adjusted for diabetes status and diuretic treatment.

\subsection{Comparison of Nutrients Intakes}

Compared to controls, the diet of patients from the ALICIR study had lower contents of proteins, especially animal proteins, lipids (including SFA and PUFA), and alcohol. Conversely, they had higher carbohydrates and sodium, intakes (Table 4). Prevalence of inadequacy regarding EAR was significantly higher in cases for vitamins B6, C, and E. Results were similar for the two aetiologies, except for fat intakes, which were lower than in the control group for patients with viral LC, while they were higher in patients with alcoholic cirrhosis (Supplemental Table S2). 
Table 4. Comparison of adjusted nutrient intakes between controls and cases $(N=522)$.

\begin{tabular}{|c|c|c|c|}
\hline & ALICIR & NutriNet & $p^{*}$ \\
\hline Total energy intake (kcal/day) & $2104.4(84.4)$ & $2202.8(93.3)$ & 0.23 \\
\hline Proteins (\%TEI) & $17.7(0.4)$ & $18.5(0.5)$ & 0.03 \\
\hline Animal proteins (\%TEI) & $12.6(0.47)$ & $13.3(0.5)$ & 0.11 \\
\hline Vegetable proteins (\%TEI) & $5.1(0.2)$ & $5.2(0.2)$ & 0.41 \\
\hline Carbohydrates (\%TEI) & $45.8(0.9)$ & $38.4(1.0)$ & $<0.0001$ \\
\hline Simple carbohydrates (\%TEI) & $21.6(0.7)$ & $17.9(0.8)$ & $<0.0001$ \\
\hline Lipids (\%TEI) & $34.8(0.8)$ & $38.1(0.9)$ & $<0.0001$ \\
\hline SFA (\%TEI) & $13.3(0.4)$ & $14.5(0.4)$ & $<0.01$ \\
\hline MUFA (\%TEI) & $13.4(0.4)$ & $14.5(0.4)$ & $<0.01$ \\
\hline PUFA (\%TEI) & $5.6(0.3)$ & $6.2(0.3)$ & $<0.01$ \\
\hline Alcohol (\%TEI) & $1.7(0.5)$ & $4.5(0.6)$ & $<0.0001$ \\
\hline Sodium (mg/day) & $3289.8(126.8)$ & $2879.3(140.2)$ & $<0.0001$ \\
\hline \multicolumn{4}{|c|}{ Prevalence of inadequacy regarding Estimated Average Requirements $(E A R, N, \%)^{\dagger}$} \\
\hline Vitamin A & $99(56.9 \%)$ & $170(50.6 \%$ & 0.17 \\
\hline Beta-caroten & $78(44.8 \%)$ & $129(37.1 \%)$ & 0.09 \\
\hline Vitamin B1 & $109(62.6 \%)$ & $183(52.6 \%)$ & 0.03 \\
\hline Vitamin B6 & $79(45.4 \%)$ & $108(31.0 \%)$ & $<0.01$ \\
\hline Vitamin B12 & $41(23.6 \%)$ & $54(15.5 \%)$ & 0.02 \\
\hline Vitamin C & $69(39.7 \%)$ & $103(29.6 \%)$ & 0.02 \\
\hline Vitamin E & $77(44.2 \%)$ & $114(32.8 \%)$ & 0.01 \\
\hline
\end{tabular}

Abbreviations: EAR: Estimated Average Requirements, TEI: Total Energy Intake. ${ }^{*}$ ANCOVA tests adjusted for marital status, professional status, smoking status and physical activity. For alcohol, tests were also adjusted for total energy intake. ${ }^{\dagger}$ Chi-square tests were performed. EAR for adult men: Vitamin A: $570 \mu \mathrm{g} /$ day; Vitamin B1: $1.50 \mathrm{mg} /$ day; Vitamin B6: $1.80 \mathrm{mg}$ /day; Vitamin B12: $4.00 \mu \mathrm{g} /$ day; Vitamin C: $90.0 \mathrm{mg}$ /day; Vitamin E: $10.50 \mathrm{mg} /$ day. EAR for adult women: Vitamin A: $490 \mu \mathrm{g} /$ day; Vitamin B1: $1.20 \mathrm{mg} /$ day; Vitamin B6: $1.50 \mathrm{mg} /$ day; Vitamin B12: $4.00 \mu \mathrm{g} /$ day; Vitamin C: $90.0 \mathrm{mg} /$ day; Vitamin E: $9.90 \mathrm{mg} /$ day. For beta-carotene, usual intakes among the general population were used: $3228.80 \mu \mathrm{g} /$ day for both men and women.

\section{Discussion}

In this case-control study, we compared food consumption and nutrient intakes between patients with a compensated and non-complicated LC and controls from the general population. The results showed that dietary and nutritional profiles of patients with LC differed from those of controls, and between the two aetiologies of LC (alcohol and virus). To the best of our knowledge, this is the first study focusing on dietary behaviour and nutritional intakes of patients with a compensated non-complicated LC performed in Europe.

In line with previous studies, our results showed that dietary behaviours of patients with LC differed from those of controls. First of all, overall dietary behaviour of patients tended to be less healthy. They had a lower consumption of legumes, vegetable fat, and soft and non-sugared beverages, and higher intakes of sodas, sauces, and desserts. Similar results were shown by Loguercio and colleagues, in a case-control study performed on 40 patients with either alcoholic or viral LC and 30 controls [25]. Compared to controls, cases ate less salty snacks and had lower intakes of alcohol. Overall, these results are consistent with nutritional guidelines for LC patients, which recommend the avoidance of alcohol consumption and moderate sodium intakes [25-27].

However, we also found that dietary habits differed according to the LC aetiology, especially regarding sweet products and starches, which were consumed in higher amounts in alcoholic LC patients compared to controls, and not in viral LC patients [25]. Given the potential impact of sugar intake on LC complications, these results suggest that patients may have differing levels of risk depending on the aetiology of LC.

Regarding the nutritional status, patients tended to have diets with higher intakes of carbohydrates, at the expense of protein (in particular animal protein) and lipid intakes patients compared to controls. This is in line with previous studies that showed higher prevalence of protein-energetic malnutrition in patients with cirrhosis, including in the early history of the 
disease $[1,10,28]$. Given this knowledge, the European Society for Clinical Nutrition and Metabolism (ESPEN) established specific guidelines (last update in April 2006) for patients with a liver disease and transplantation $[27,29]$. The recommended intakes of energy and proteins for patients with compensated and non-complicated cirrhosis are 35-40 kcal/ kg/day and $1.2-1.5 \mathrm{~g} / \mathrm{kg} /$ day, respectively. In our study, daily energy intakes were lower than this bound in both alcoholic and viral cirrhosis $(30.1 \pm 1.8 \mathrm{kcal} / \mathrm{kg} /$ day and $26.8 \pm 1.6 \mathrm{kcal} / \mathrm{kg} /$ day respectively). The daily amounts of protein intakes reached the recommendations for patients with an alcoholic cirrhosis $(1.3 \pm 0.1)$, but not for patients with a viral cirrhosis $(1.1 \pm 0.1)$. Therefore, though our study did not show significant differences between cases and controls for energy intakes, the specific requirements for energy intakes in patients were not reached. Moreover, the cases in our study showed higher sodium intakes than controls, and intakes over $3 \mathrm{~g} /$ day, while the ESPEN guidelines recommend a salt-restricted diet (2-3 g of salt, corresponding to $5-7 \mathrm{~g}$ of salt per day) especially in the case of hydro sodium retention. However, the patients of ALICIR have a clinical presentation of compensated and non-complicated cirrhosis, thus, with the exception of specific diets related to comorbidities, such as heart failure, patients were not usually encouraged to adopt a salt-free or salt-restricted diet. Then, it is expected that the behavior of patients regarding the salt consumption is similar to those of the general population. The difference we showed between cases and controls could partly be due to increased intakes of sauces, cereal bread, and processed meat in patients, which are the main sources of salt in the French diet [30]. Finally, the assessment of sodium could be less accurate for volunteers. Indeed, web-based self-administered questionnaires tend to minimize the salt consumption [31,32].

We found high water-and soda—consumption in cases, rising up to a mean $1.8 \mathrm{~L} \pm 81 \mathrm{~mL}$ per day compared to $933 \pm 85 \mathrm{~mL}$ per day in controls. The relation between cirrhosis and renal function is not well understood, and is subject to extensive research. However, several studies have highlighted an internal dysregulation of the renin system in patients with stable LC $[33,34]$. The elevated beverage intakes in patients may, therefore, be consistent with preclinical renal dysfunction symptoms, even at this early stage of the disease. An alternative explanation would be related to a modification of dietary behaviour, with the replacement of other beverages, like coffee, tea or, more specifically, alcoholic beverage in patients with alcoholic LC by water. To our knowledge, this is the first study to identify this specific pattern of beverage consumption in LC patients. Further studies are required to better understand the determinants of such consumption, and investigate the potential relationship between liver and renal malfunctions.

This study has numerous strengths that ensure reliable results. First, patients were unambiguously identified with biopsy-proven cirrhosis and were selected with stringent criteria regarding liver function. Second, we were able to match patients with a large number of controls from the general population, using a large set of matching criteria limiting the differences between patients and controls. Third, while most studies in LC patients focused on proteins and energy intakes, to investigate protein-energy malnutrition, we were able to compare a wider spectrum of dietary data. Finally, the food frequency questionnaire that was used in both patients and controls to assess dietary behaviour, was previously validated in a French population, and showed good validity and reproducibility [18].

This study, however, presents some limitations. Though we used a large set of variables to match cases and controls, some specific aspects that impact dietary behavior were not taken into account. Indeed, cases included a large share of patients with having a history of migration (North and sub-Saharan Africa for almost two thirds of the patients), which could, in part, explain the differences observed, since dietary behavior is largely influenced by socio-cultural background [35]. We were not able to compare ethnic backgrounds between cases and controls, since this information is not collected in the Nutrinet Santé study (this is due to the French legislation regarding personal data collection). However, dietary habits have been shown to be altered following immigration, and the combination of a traditional diet with items from the western diet is frequently observed [36]. Moreover, participants included in the NutriNet-Santé cohort are adult volunteers and are, therefore, more likely to be 
interested in nutrition and, therefore, adopt healthier dietary and lifestyle behaviors than the general population, which could have widened the observed differences between cases and controls [37]. This assumption was supported by the differences we showed between cases and controls regarding smoking status, occupational status, and physical activity level (Tables 1 and 2). Thus, an alternative method to conduct the study could be the comparison of patients with their healthy relatives, so that the ethical or familiar peculiarity in diet habits could be minimized. Finally, the different method used for the completion of the food questionnaires (i.e., web self-administered versus hetero-administration by a dietician) could have partly impacted the dietary and/or nutritional information. Yet, web-based self-administered Food Frequency Questionnaire (FFQ) have shown their validity and reproducibility in comparison with the same questionnaire using a hetero-administration [38].

\section{Conclusions}

In this case-control study, patients with non-complicated and compensated LC showed overall less healthy dietary habits compared to controls, which somewhat differed according to the origin of the cirrhosis. Additionally, patients did not meet the European nutritional guidelines regarding protein, energy, and sodium intakes, especially in the case of viral cirrhosis. Long-term follow-up of these patients among the ALICIR study should contribute to increasing the knowledge of how nutritional and dietary factors influence the progression of the disease, especially regarding the occurrence of HCC.

Supplementary Materials: The following are available online at www.mdpi.com/2072-6643/10/1/60/s1, Table S1: Comparison of dietary intakes stratified on the aetiology of cirrhosis $(N=522)$; Table S2: Comparison of nutrient intakes stratified on the aetiology of cirrhosis $(N=522)$.

Acknowledgments: The ALICIR study is supported by ANRS (France Recherche Nord and Sud Sida-HIV Hépatites). CIRRAL has been funded by the National Institute of Cancer (INCa, Institut National du Cancer), the ARC foundation and ANRS. The ANRS CO12 CirVir cohort is sponsored and funded by ANRS. The NutriNet-Santé Study is supported by the French Ministry of Health, the Sante publique France Institute, the Institut National de la Santé et de la Recherche Médicale, the Institut National de la Recherche Agronomique, the Conservatoire National des Arts et Métiers and the Fondation pour la Recherche Médicale and Paris 13 University. The funding sponsor had no role in the design or conducting of the study, collection, management, analysis, interpretation of data, nor preparation, review or approval of the manuscript. This work is dedicated to the memory of Jean-Claude Trinchet. We especially thank Cédric Agaësse, Claudia Chahine, and Marion Genest (dieticians) for the data collection, and Nathalie Arnault (statistician) for the data management and analysis. We thank the scientists, dietitians, technicians, and assistants who helped to carry out NutriNetSanté test studies, and all dedicated and conscientious volunteers.

Author Contributions: C.B. helped with the statistical analyses, and wrote and revised the paper. V.B. and S.B. helped in the interpretation of the results, and critically revised the paper for important intellectual content. L.K.F., D.R., C.C. and Z.B.-A. critically revised the paper for important intellectual content. V.B., P.N. and S.H. were involved in the conception and design of the research and critically revised the paper for important intellectual content. C.J. and N.G.-C. were involved in the formulation of the research question and the design of the study, supervised the analyses and had primary responsibility for the final content. All authors have read and approved the final manuscript.

Conflicts of Interest: The authors declare no conflict of interest.

\section{References}

1. Alberino, F.; Gatta, A.; Amodio, P.; Merkel, C.; Di Pascoli, L.; Boffo, G.; Caregaro, L. Nutrition and survival in patients with liver cirrhosis. Nutrition 2001, 17, 445-450. [CrossRef]

2. Merli, M.; Nicolini, G.; Angeloni, S.; Riggio, O. Malnutrition is a risk factor in cirrhotic patients undergoing surgery. Nutrition 2002, 18, 978-986. [CrossRef]

3. Tajika, M.; Kato, M.; Mohri, H.; Miwa, Y.; Kato, T.; Ohnishi, H.; Moriwaki, H. Prognostic value of energy metabolism in patients with viral liver cirrhosis. Nutrition 2002, 18, 229-234. [CrossRef]

4. Sam, J.; Nguyen, G.C. Protein-calorie malnutrition as a prognostic indicator of mortality among patients hospitalized with cirrhosis and portal hypertension. Liver Int. Off. J. Int. Assoc. Study Liver 2009, 29, 1396-1402. [CrossRef] [PubMed] 
5. Ney, M.; Abraldes, J.G.; Ma, M.; Belland, D.; Harvey, A.; Robbins, S.; Den Heyer, V.; Tandon, P. Insufficient Protein Intake Is Associated With Increased Mortality in 630 Patients With Cirrhosis Awaiting Liver Transplantation. Nutr. Clin. Pract. 2015, 30, 530-536. [CrossRef] [PubMed]

6. Cammà, C.; Petta, S.; Di Marco, V.; Bronte, F.; Ciminnisi, S.; Licata, G.; Peralta, S.; Simone, F.; Marchesini, G.; Craxì, A. Insulin resistance is a risk factor for esophageal varices in hepatitis $\mathrm{C}$ virus cirrhosis. Hepatology 2009, 49, 195-203. [CrossRef] [PubMed]

7. Perez-Martinez, P.; Mikhailidis, D.P.; Athyros, V.G.; Bullo, M.; Couture, P.; Covas, M.I.; de Koning, L.; Delgado-Lista, J.; Diaz-Lopez, A.; Drevon, C.A.; et al. Lifestyle recommendations for the prevention and management of metabolic syndrome: An international panel recommendation. Nutr. Rev. 2017, 75, 307-326. [CrossRef] [PubMed]

8. Yu, L.; Morishima, C.; Ioannou, G.N. Dietary Cholesterol Intake is Associated with Progression of Liver Disease in Patients with Chronic Hepatitis C: Analysis of the Hepatitis C Antiviral Long-term Treatment Against Cirrhosis Trial. Clin. Gastroenterol. Hepatol. 2013, 11, 1661-1666. [CrossRef] [PubMed]

9. Berzigotti, A.; Albillos, A.; Villanueva, C.; Genescá, J.; Ardevol, A.; Augustín, S.; Calleja, J.L.; Bañares, R.; García-Pagán, J.C.; Mesonero, F.; et al. Effects of an intensive lifestyle intervention program on portal hypertension in patients with cirrhosis and obesity: The SportDiet study. Hepatology 2017, 65, 1293-1305. [CrossRef] [PubMed]

10. Carvalho, L.; Parise, E.R. Evaluation of nutritional status of nonhospitalized patients with liver cirrhosis. Arq. Gastroenterol. 2006, 43, 269-274. [CrossRef] [PubMed]

11. Somi, M.H.; Rahimi, A.O.; Moshrefi, B.; Rezaeifar, P.; Maghami, J.G. Nutritional status and blood trace elements in cirrhotic patients. Hepat. Mon. 2007, 7, 27-32.

12. Yasutake, K.; Bekki, M.; Ichinose, M.; Ikemoto, M.; Fujino, T.; Ryu, T.; Wada, Y.; Takami, Y.; Saitsu, H.; Kohjima, M.; et al. Assessing current nutritional status of patients with HCV-related liver cirrhosis in the compensated stage. Asia Pac. J. Clin. Nutr. 2012, 21, 400-405. [PubMed]

13. Hayashi, F.; Momoki, C.; Yuikawa, M.; Simotani, Y.; Kawamura, E.; Hagihara, A.; Fujii, H.; Kobayashi, S.; Iwai, S.; Morikawa, H.; et al. Nutritional status in relation to lifestyle in patients with compensated viral cirrhosis. World J. Gastroenterol. 2012, 18, 5759-5770. [CrossRef] [PubMed]

14. Trinchet, J.-C.; Bourcier, V.; Chaffaut, C.; Ait Ahmed, M.; Allam, S.; Marcellin, P.; Guyader, D.; Pol, S.; Larrey, D.; De Lédinghen, V.; et al. Complications and competing risks of death in compensated viral cirrhosis (ANRS CO12 CirVir prospective cohort). Hepatology 2015, 62, 737-750. [CrossRef] [PubMed]

15. Ganne, N.; Bourcier, V.; Chaffaut, C.; Archambaud, I.; Oberti, F.; Perarnau, J.-M.; Roulot, D.; Louvet, A.; Moreno, C.; Dao, T.; et al. G08: Incidence of hepatocellular carcinoma (HCC) and complications in alcoholic compensated cirrhosis. Preliminary results of a multicenter prospective French and Belgian cohort (INCA Cirral). J. Hepatol. 2015, 62, S213-S214. [CrossRef]

16. Hercberg, S.; Castetbon, K.; Czernichow, S.; Malon, A.; Mejean, C.; Kesse, E.; Touvier, M.; Galan, P. The Nutrinet-Santé Study: A web-based prospective study on the relationship between nutrition and health and determinants of dietary patterns and nutritional status. BMC Public Health 2010, 10, 242. [CrossRef] [PubMed]

17. Accueil I ANRS. Available online: http:/ / www.anrs.fr / fr (accessed on 9 January 2018).

18. Kesse-Guyot, E.; Castetbon, K.; Touvier, M.; Hercberg, S.; Galan, P. Relative Validity and Reproducibility of a Food Frequency Questionnaire Designed for French Adults. Ann. Nutr. Metab. 2010, 57, 153-162. [CrossRef] [PubMed]

19. Hercberg, S. Su.Vi.Max: Portions Alimentaires; Manuel Photos Pour L'estimation des Quantités-(Su.Vi.Max. Photograph Book for the Estimation of Portion Sizes); Polytechnica: Paris, France, 2012.

20. Craig, C.L.; Marshall, A.L.; Sjöström, M.; Bauman, A.E.; Booth, M.L.; Ainsworth, B.E.; Pratt, M.; Ekelund, U.; Yngve, A.; Sallis, J.F.; et al. International Physical Activity Questionnaire: 12-Country Reliability and Validity. Med. Sci. Sports Exerc. 2003, 35, 1381-1395. [CrossRef] [PubMed]

21. INSEE Définition-Unité de Consommation / Insee. Available online: https:// www.insee.fr/fr/metadonnees / definition/c1802 (accessed on 31 January 2017).

22. Carriquiry, A. Assessing the Prevalence of Nutrient Inadequacy; CARD Staff Reports; Center for Agricultural and Rural Development: Ames, IA, USA, 1998; p. 25. 
23. Agence Nationale de Sécurité Sanitaire de L'alimentation, de L'environnement et du Travail (ANSES). Actualisation des Repères du PNNS: Révision des Repères de Consommations Alimentaires-Rapport D'expertises Collectives; ANSES: Maison-Alfort, France, 2016.

24. Analytics, Business Intelligence and Data Management. Available online: https://www.sas.com/en_us / home.html (accessed on 4 September 2017).

25. Loguercio, C.; Blanco, F.D.; Nastasi, A.; Federico, A.; Blanco, G.D.; De Girolamo, V.; Disalvo, D.; Parente, A.; Blanco, C.D. Can dietary intake influence plasma levels of amino acids in liver cirrhosis? Dig. Liver Dis. 2000, 32, 611-616. [CrossRef]

26. Zeanandin, G.; Thibault, R.; Bachmann, P.; Coti-Bertrand, P.; Guex, E.; Quilliot, D. Nutritional management in liver cirrhosis. Nutr. Clin. Metab. 2013, 27, 102-104. [CrossRef]

27. Plauth, M.; Cabré, E.; Riggio, O.; Assis-Camilo, M.; Pirlich, M.; Kondrup, J.; Ferenci, P.; Holm, E.; vom Dahl, S.; Müller, M.J.; et al. ESPEN Guidelines on Enteral Nutrition: Liver disease. Clin. Nutr. 2006, 25, 285-294. [CrossRef] [PubMed]

28. Caregaro, L.; Alberino, F.; Amodio, P.; Merkel, C.; Bolognesi, M.; Angeli, P.; Gatta, A. Malnutrition in alcoholic and virus-related cirrhosis. Am. J. Clin. Nutr. 1996, 63, 602-609. [CrossRef] [PubMed]

29. Plauth, M.; Merli, M.; Kondrup, J.; Weimann, A.; Ferenci, P.; Müller, M.J.; ESPEN Consensus Group. ESPEN guidelines for nutrition in liver disease and transplantation. Clin. Nutr. 1997, 16, 43-55. [CrossRef]

30. World Health Organization. Guideline: Sodium Intake for Adults and Children; WHO: Geneva, Switzerland, 2012; ISBN 978-92-4-150483-6.

31. Fallaize, R.; Forster, H.; Macready, A.L.; Walsh, M.C.; Mathers, J.C.; Brennan, L.; Gibney, E.R.; Gibney, M.J.; Lovegrove, J.A. Online Dietary Intake Estimation: Reproducibility and Validity of the Food4Me Food Frequency Questionnaire Against a 4-Day Weighed Food Record. J. Med. Internet Res. 2014, 16. [CrossRef] [PubMed]

32. Forster, H.; Fallaize, R.; Gallagher, C.; O’Donovan, C.B.; Woolhead, C.; Walsh, M.C.; Macready, A.L.; Lovegrove, J.A.; Mathers, J.C.; Gibney, M.J.; et al. Online Dietary Intake Estimation: The Food4Me Food Frequency Questionnaire. J. Med. Internet Res. 2014, 16. [CrossRef] [PubMed]

33. Magri, P.; Auletta, M.; Andreucci, M.; Somma, G.; Musone, D.; Fiorillo, M.; Torraca, S.; Antoniello, S.; Cianciaruso, B. Sodium retention in preascitic stage of cirrhosis. Semin. Nephrol. 2001, 21, 317-322. [CrossRef] [PubMed]

34. Fialla, A.D.; Thiesson, H.C.; Bie, P.; Schaffalitzky de Muckadell, O.B.; Krag, A. Internal dysregulation of the renin system in patients with stable liver cirrhosis. Scand. J. Clin. Lab. Invest. 2017, 77, 298-309. [CrossRef] [PubMed]

35. Osei-Kwasi, H.A.; Nicolaou, M.; Powell, K.; Terragni, L.; Maes, L.; Stronks, K.; Lien, N.; Holdsworth, M. Systematic mapping review of the factors influencing dietary behaviour in ethnic minority groups living in Europe: A DEDIPAC study. Int. J. Behav. Nutr. Phys. Act. 2016, 13, 85. [CrossRef] [PubMed]

36. Gilbert, P.A.; Khokhar, S. Changing dietary habits of ethnic groups in Europe and implications for health: Nutrition Reviews( ). Nutr. Rev. 2008, 66, 203-215. [CrossRef] [PubMed]

37. Andreeva, V.A.; Deschamps, V.; Salanave, B.; Castetbon, K.; Verdot, C.; Kesse-Guyot, E.; Hercberg, S. Comparison of Dietary Intakes Between a Large Online Cohort Study (Etude NutriNet-Sant) and a Nationally Representative Cross-Sectional Study (Etude Nationale Nutrition Sant,) in France: Addressing the Issue of Generalizability in E-Epidemiology. Am. J. Epidemiol. 2016, 184, 660-669. [CrossRef] [PubMed]

38. Labonté, M.-È.; Cyr, A.; Baril-Gravel, L.; Royer, M.-M.; Lamarche, B. Validity and reproducibility of a web-based, self-administered food frequency questionnaire. Eur. J. Clin. Nutr. 2012, 66, 166. [CrossRef] [PubMed]

(C) 2018 by the authors. Licensee MDPI, Basel, Switzerland. This article is an open access article distributed under the terms and conditions of the Creative Commons Attribution (CC BY) license (http:/ / creativecommons.org/licenses/by/4.0/). 